\title{
The Role of the Purges Towards Massive Range of Bureaucrats played in Julian's Imperial Control
}

\author{
Jiazhen Jiang ${ }^{1, *}$
}

\author{
${ }^{1}$ No. 2 High School Of East China Normal University \\ *Email: jiangjiazhen@hsefz.cn
}

\begin{abstract}
Julian was the last non-christian Roman emperor from 361 to 363. During his reign he prompted many revolutions on religion and politics, and also led the important war against Persian. Researches had done sufficient analysis on the macro level of these fields, and especially in the field of religion. Nevertheless, the research of the effect of many events in the micro level had on Julian's ruling is still lacking. Based on Ammianus Marcellinus's work Res Gestae, we used a historical perspective to discuss whether the purges happened during Julian's political revolution enhanced the imperial control by viewing the role of purges during the process of building the empire's justice and credibility as well as the legitimacy of Julian as an Augustus. The conclusion shows a rather positive relationship between the purges and Julian's control over the empire, but also some negative social outcomes caused by the purges which showed the failure of purges on enhancing the imperial control existed in certain region. Moreover, this research is not just for clarifying the relationship between the purges happened during Julian's reign and the controlling of the whole Rome Empire of this period of time, but can provide a point of view of the general relationship between purges and imperial control.
\end{abstract}

Keywords: Rome empire, Julian, Purge, Imperial Control.

\section{INTRODUCTION}

Julian (Latin: Flavius Claudius Julianus) was appointed by Constantius II to be the next emperor of the Rome Empire in 361. After he arrived at Thrace and succeeded the throne, Julian immediately formed a special tribunal called Chalcedon Tribunal, with this organization he judged and executed or exiled many of the bureaucrats. Things were not end after the massive executions, another large group of bureaucrats was executed during late 361 and early 362. The executions of these two period of times can be viewed as two parts of a series purges happened in Julian's reign. In the following pages, I will be discussing about the influence purges had on Julian's imperial control.

There are already many researches had been done on Julian together with the events (including these purges I mentioned) happened under his rule, but the main arguments of these articles are between the origin and the details of these purges, the event directly related with these purges as well as the analysis towards Julian's way of ruling on a general level.
On page 74 of E.A. Thompson's book The historical work of Ammianus Marcellinus, he used the fact of four of the judgers of Chalcedon Tribunal had the experience of following and working for Constantius II to analysis the details which can prove the justice of the tribunal[1]. Similarly, in Shaun Tougher's book Julian the Apostate the author also made an analysis towards the first months of Julian's sole rule which contains the part of Chalcedon Tribunal, but his argument was for proving Julian was an experienced dissembler [2]. Around the Chalcedon Tribunal another research was done by Larry Reedy, in his article Justice at Chalcedon: A Defense of Julian's Political Tribunal he viewed the tribunal together with Julian's Neo-Platonist concept of justice, which provides a thought about the essence of the Chalcedon Tribunal [3].

About the event related with the purges, which is the riot of Alexandria 361, researches provided us with the exact time point of the event as well as the religious situation in Alexandria before 361 as a premise to the event. On page 2 of Lauren Kaplow's article Religious and Intercommunal Violence in Alexandria in the 4th and 5th centuries CE, she discussed about the actual 
time point of the riot of Alexandria 361 [4]. With The Murder of George of Cappadocia and the Violent Pagan Image in Ammianus Marcellinus, Shunsuke Kosaka provided the analysis of religious situation in Alexandria region, indicated that the chaotic religious environment may be the long term cause of the riot [5].

With a general sight, Marshall Lilly connected the experience of Julian with his way of controlling the empire through her article Companion to the gods, friend to the empire: the experiences and education of the emperor Julian and how it influenced his reign [6]. Also, Bruno Bleckmann analyzed the political system at that time and discussed about Julian's legitimacy as an Augustus in From Caesar to Augustus: Julian against Constantius [7].

Also, as for the execution of Gallus the Caesar in 354 which was related with the purges, R. C. Blockley did a research on analyzing Gallus and especially the relationship with Julian in his article Constantius Gallus and Julian as Caesars of Constantius II [8].

With these researches, details of the Purges and the characteristics of imperial control applied by Julian are already clear. But the relationship between the purges and the emperor's control of the empire was still not indicated clearly. Since the purges were considered to be important political actions of Julian, it is worthy to explore the influence purges had on imperial control. With the research I give in the followings, I believed that the question of whether purges enhanced the imperial control of Julian could be answered.

\section{PURGES IN JULIAN'S REIGN}

Purge is referred in the dictionary as "to remove people from an organization, often violently, because their opinions or activities are unacceptable to the people in power". Along the history Purge, as a device of the despotic power, been used many times by the rulers for lots of purposes. During Julian's regime there were mainly two periods of time of purge, which many of executions happened, and each of these executions had different effect on the emperor's control over the empire.

\subsection{The First Purge In 361, After The Succeed Of Julian.}

The first purge was recorded by Ammianus in Book XXII paragraph 3 as: "Some adherents of Constantius are condemned to death, a part justly, others unjustly." [9].The time of the purge however, was just after Julian success from the previous emperor Constantius II. During this period of time, a special court called "Chalcedon tribunal" was made by Julian, and made lots of judgement upon a massive range of people. The court was described in Book XXII paragraph 3.2 like:
"These crossed all to Chalcedon, and in the presence of the generals and tribunes of the Joviani and the Herculiani examined the cases with more passion than was just and right..." [9], showed that it was more than an organization that punish the guilty, but should be viewed as a tool to fulfill some of the emperor's goals since the court was set up by the Emperor. Hence, it is worthy to ask what role did purge play in that situation and whether this action enhanced Julian's control over the empire. With the specific names and reasons of been executed Ammianus recorded in his book, it is possible to say that the purge did enhance the imperial control by settling the society, stopping the corruption among elites and most importantly regaining the Emperor Julian's credibility and enhancing his legitimacy of succeed.

\subsubsection{The Purge At Social Level}

Considering at a social level, the purge played a great role on rebuilding the trust of the people towards the emperor since the emperor followed the willing of the commons and executed many of the guilty. The guilty in here, mainly refers to those regional governors who lost the credibility from the commons, because of making harsh policies and showing endless cruelty to the people. For the commons, the policies of regional governors are directly related to their survivals. With harsh policies, maybe the law is too strict, so that people will be punished for any mistake; Or the taxation is so heavy that people cannot survive even when they have a good harvest, the conflict between ruler and the people will inevitably show, make the society lose stability. At this time, an execution of the regional governor from the emperor, even not necessary to base on the law, can rebuild people's trust towards the empire by making the emperor the representative of justice, thus consolidating the rule. For Julian, this was extremely important after having a civil war with the previous emperor Constantius II. A specific example is Paulus, the execution of him been recorded in the Book XXII paragraph 3.11 as “...was burned alive, as well as Paulus the notary, surnamed Catena, a man to be mentioned by many with groans, who thus met the fate which was to have been hoped for." [9]. Paulus was dispatched to Roman Britain by the Emperor Constantius II to control subversive elements in 353[10], and so harsh were his measures that he earned the nickname Catena meaning 'The Chain', because he chained many people and dragged them with their chains through the streets. Also, Ammianus in his book mentioned that in 355 he was ordered to hunt down the followers of another usurper Claudius Silvanus in Gaul, again he tortured and killed people there. Considering the experience of Julian in Gaul, he probably heard of the infamous name of Paulus which is enough for him to execute Paulus to reassure the people. Just as Ammianus recorded in Book XXII 3.10, the 
execution was considered as "proper vigour and severity" [9], and successfully settling the society by regaining the trust from people. From this result, Purge did enhance Julian's control over the empire at a social level.

\subsubsection{The Purge During Elites and Army}

The purge largely enforce the controlling power by cleaning up the elites and the army, since it stopped the corruption existing among these two groups. Corruption can be considered as an important element of the collapse of a state or even a whole empire, and the corruption happened during the regime of Constantius was extremely severe, and even the army was effected. Inside the palace of Constantius, corruption was happening everywhere and countless crimes had arisen from it. The greedy of these attendants was mentioned like: "For some of them...knew no limit to bribery, robbery, and extravagance, always accustomed as they were to seize the property of others. Hence sprang the seeds of a dissolute life... and their mad pride stained their honour by shameful gains." (Book XXII 4.3) [9]. Moreover, everything happened in this palace, which was considered to be the sacred place for which the emperor was living in, would be immitated by all the class of bureacrats over the empire, as described by Ammianus: "But it must be admitted that the major part of those creatures maintained a vast nursery of all the vices, to such a degree that they infected the state with evil passions, and rather by their example than by their license in wrong-doing injured many."(Book XXII 4.2)[9]. What is more frightening was, the army was also drown by the corruption. For the army, the book said: "In place of the war-song the soldiers practised effeminate ditties; the warriors' bed was not a stone (as in days of yore), but feathers and folding couches; their cups were now heavier than their swords (for they were ashamed to drink from earthenware)." (Book XXII 4.6) [9]. The army had a great job of maintaining the safety of the empire both internally and externally. Once the army is corrupted, the empire would be armless when facing the internal rebellion or the external invasion. Under this situation a purge was more than necessary for the emperor in order to recover the power of the empire. The punishment of Euagrius, Saturninus and Cyrinus, as the culprits of the corruption, were recorded in Book XXII paragraph 3.7: "In like manner Euagrius, count of the privy purse, and Saturninus, former steward of the household, and Cyrinus, a former secretary, were all exiled." [9]. It is interesting that they were exiled instead of been killed, likely was because these people actually did not have political standings, there was no need to executed them to reclaim the power in their hands. Also, exile is a much more public form of punishment than execution, since the living of these people could be more influential than their deaths, and with their living Julian wanted to show the integrity to the Commons, as described in the book the emperor allowed the attendants of the palace to "go wherever they wished." (Book XXII 4.10) [9]. Since after the purge towards those corrupted elites Julian warned the rest and was able to stop the corruption, it is obvious the purge enhanced the emperor's control over the empire.

\subsubsection{The Purge of Bureaucrats Related With Gallus's Execution}

During the purge Julian executed the bureaucrats related with the execution of Gallus in 354, which disconnected himself from the crime and reduced the negative effect of the execution. With the help of the purge, Julian was able to rebuild his credibility and enhance his legitimacy. Constantius Gallus (326-354) was a statesman and ruler in the eastern provinces of the Roman Empire from 351 to 354, as Caesar under emperor Constantius II (r. 337-361). In 354, Gallus was summoned by Constantius and been executed in Pola because of his terrorization policies. Importantly, Julian was actually half brother of Gallus, and after the execution he was accused for treason and was imprisoned by the emperor Constantius II ( "Ursicinus, commander of the cavalry in the Orient, Julian, brother of Gallus Caesar, and Gorgonius, his grand chamberlain, are accused of treason." Book XV 2.7) [9]. As for an emperor, having blood relationship with a tyrant and having the history of being accused for treason is devastating, because it will make the emperor lose credibility among the commons, even if there was no such thing happened. The rumor can be destructive just as the truth, and sometimes even more. Therefore, although the power of Julian was legally succeed from the previous emperor Constantius, been recorded as: "...the envoys Theolaifus and Aligildus, who had been sent to him, suddenly appeared and reported the death of Constantius, adding that with his last words he had made Julian the successor to his power." (Book XXII 2.1) [9], The words should be viewed with suspicion, since it was recorded by Ammianus, both the assistant of Julian and a fan of him. But no research seems to suggest that Julian's succession was illegal. There was still need for him to reinforce his legitimacy and credibility. The purge of the four people, Palladius, Apodemius, Pentadius and Eusebius, enabled Julian to fulfill his goal. From the cases of Palladius, Apodemius and Eusebius, it is possible that with the punishment of these three people, Julian was able to show that the execution of Gallus was driven largely by individual words and passions instead of justice. Palladius was the formerly chief marshal of the court under Gallus the Caesar, and was exiled because of the suspicion of defamation against Gallus, as been recorded by Ammianus: "At first they banished to Britain Palladius, who was brought before them on the suspicion of having made certain charges to Constantius against Gallus.” (Book XXII 3.3) [9]. Apodemius also took part 
in the case of Gallus as a secret service of Constantius(Book XIV 11.19), and Ammianus defined Apodemius as "showed unbridled eagerness for the death of Silvanus and Gallus"(Book XXII 3.11) [9]. As for Eusebius, he was the great chamberlain and did corruption in the Gallus case which be recorded in Book XIV 10.5 as "Eusebius, the high chamberlain, was sent to Cabillon with a large sum of money, which he distributed secretly among the chief leaders of sedition."'[9], which gives Julian another way to show the injustice of the execution of Gallus. Pentadius was actually a special example, who actually survived from the purge. Pentadius was sent by Constantius to interrogate Gallus, and he also took part in the final execution. According to Ammianus, he was probably accused because of "took down in shorthand the answers that Gallus had made to the many questions put to him." [9]. If the officer that taking both part in the interrogation and execution been executed because of his recording of Gallus's answer, the very basis of this case would collapse. The case of Pentadius shows that Julian was not just want to reduce the negative impact, but also want to rehabilitate Gallus, although this attempt failed at last.

Through the purge of the people involved in the Gallus case, the thought that the execution happened in 354 was lack of justice could be released, since Julian put the right charges on them all. For the common people, there is no way for them to know the details of the execution of Gallus, the only way for them to know about it was from the formal action towards the case. Hence, Julian was able to reduce the effect of Gallus through the purge even if his cruelty actually harmed his region. Also, the suspicion of Julian's treason faded as the Gallus case no longer being a political stain of his, and the emperor's legitimacy was perfected. Therefore, the purge enhance the imperial control by disconnecting Julian with the crime and strengthening his legitimacy

\subsubsection{Objections The Purge}

There were objections appeared when Ursulus was put into death, for Ursulus was considered to be Julian's right hand man in Gaul. This execution actually harmed Julian's power since “After Ursulus's death Julian found himself the object of the reproaches and curses of many men" (Book XXII 3.8), and even "these acts which I have mentioned displeased even Julian's supporters" (Book XXII 3.10) [9]. But since Julian claimed the man who put Ursulus into death without his knowledge, and timely showed his justice by the case of Paulus as described: "yet those which follow were executed with proper vigour and severity." (Book XXII 3.11) [9], almost no damage was done because of one single case.

\subsubsection{Evaluation of The Purge}

As a policy of enhancing the imperial control, the Purge is undoubtedly a success. During the implementation stage of the policy, the success is showed both before the purge and after the purge. From the future perspective, Julian's legally succeeded power and having a powerful army under his control (as described in Book XXII 2.2: “...he ordered a march into Thrace, quickly broke camp, and passing the slope of Succi, made for Philippopolis, the ancient Eumolpias, followed with eager step by all who were under his command."[9]) formed the basis of his ability to push on the purge. From the past perspective, the purge was also succeeded in enhancing the imperial control because it settled the society, stopped the corruption as well as rebuild the emperor's credibility and reinforced his legitimacy.

\subsection{The Second Purge, Happened From Late 361 To Early 362.}

There was actually a second period of time in the regime of Julian that been considered to have a huge impact to his ruling, which was from the late 361 to the early 362. Although during this period, there were no certain records that specifically identified a purge was happened, the execution of some of the bureaucrats, for example Artemius and Gaudentius, had equally important role as the many executions of bureaucrats happened in the purge of 361. Importantly, it is hard to say that the executions in this period were completely apart from the first purge happened just after the succeed of Julian since some of the bureaucrats been executed were still connected with the case of Gallus, but consider the time difference and the situation of the society, it is possible to say that the purpose behind the second purge was different. During this period, the executions was actually more like purges rather than performances to the commons. In another word, the main purpose of the executions was actually removing people who was considered to be the obstacles to the emperor's ruling from the bureaucracy, instead of showing justice or rebuilding the emperor's legitimacy as considered to be the purpose of the first purge. From the perspective of the role the second purge played in enhancing the imperial control of Julian, the conclusion might be different with the first purge. As for the execution of Gaudentius, it was successful because the emperor's aim of removing Gaudentius from the bureaucracy was fulfilled, and almost no social effect was caused. But as for the execution of Artemius, the following social outcome was thought to have done great harm to imperial ruling, for the executions was believed to have direct relationship with the riot of Alexandria 361. Therefore, the second purge was not considered to have had a positive effect on Julian's rule. 


\subsubsection{The Case of Gaudentius}

Considering about the execution of Gaudentius, Julian successfully recovered the power from Africa and wiped out the spy Constantius II had planted beside him. Back at the time Julian was the Caesar and fighting against the German guerrillas, Gaudentius had offended Julian and was recorded by Ammianus in the Book XVII as: "he was assailed for it with slanderous speeches by Gaudentius, who was then a secretary."[9]. Morale was the most important thing before the war, and with the speech Gaudentius gave, the morale of Julian's soldier was considered to be harmed.With the experience of offending Julian, Gaudentius was chosen by Constantius II to watch Julian's action in Gaul as hinted in Book XXI 7.2: “...the secretary Gaudentius, who had been for some time in Gaul to watch the actions of Julian."'[9]. Also, this experience, on the verge of a civil war with Julian, allowed Constantius to secure his power in Africa by sending Gaudentius to Africa, as the experience ensured that Gaudentius and Julian would never be on the same side.("For he hoped that Gaudentius would be able to accomplish everything with prompt obedience for two reasons: both because he feared the adverse side, which he had offended, and because he would be eager to take advantage of this opportunity to commend himself to Constantius, who he thought would undoubtedly be the victor;" Book XXI 7.3.[9]) After Julian's succeed, Gaudentius was still a state-secretary, and the power in his hand would be very detrimental to Julian's rule. Hence, the execution of Gaudentius was considered to have successfully removed the potential threat towards the imperial control.

\subsubsection{The Case of Artemius And The Following Social Outcome}

But as for the execution of Artemius, the consequence was much more severe. The original purpose of the execution was to recover the emperor's military power Artemius had in Egypt, as well as to answer the commons' request, as described in Book XXII 11.2: "Then, too, Artemius, sometime military commander in Egypt, since the Alexandrians heaped upon him a mass of atrocious charges, suffered capital punishment." [9]. But the outcome of Alexandria region, the riot of Alexandria 361, was over the emperor's anticipation. Although the relationship between the Arian bishop of Alexandria, George the Cappadocian and Artemius was not clearly showed in Ammmianus's work, the sacking of the Temple of Serapis in Alexandria can prove that Artemius supported George and took part in his action against the pagan and orthodox Christianity. After Artemius was summoned by Julian, the chance of George lost his military support as well as the fear of Artemius's coming back driven the people of
Alexandria to have a riot, as recorded in Book XXII 11.3: "Hardly had a brief time elapsed, when the Alexandrians, on learning of the death of Artemius, whom they dreaded, for fear that he would return with his power restored (for so he had threatened) and do harm to many for the wrong that he had suffered, turned their wrath against the bishop Georgius, who had often, so to speak, made them feel his poisonous fangs."[9]. Although the outrage of the people was not directly towards the emperor or the execution itself, the riot as following social outcome showed the failure of the execution on enhancing the imperial control. Additionally, the emperor's attitude towards the consequence could also show the failure of the execution. In Book XXII 11.11, Julian showed his anger towards the riot as: "The emperor, on hearing of this abominable deed, was bent upon taking vengeance, but just as he was on the point of inflicting the extreme penalty upon the guilty parties, he was pacified by his intimates, who counselled leniency." [9]. The anger of the emperor indicates the riot was out of his predict, and as a political action the execution did fit with the expectation of the ruler means its failure. Considering of the riot the execution of Artemius caused, instead of enforce the imperial control it disturbed the stability of Alexandria region oppositely.

\section{CONCLUSION}

This paper clarified the role of purges in the regime of Julian with a historical view based on Ammianus Marcellinus's work Res Gestae. From the influence on the constructing of justice and credibility, also on the rebuilding of Julian's legitimacy, we found a positive relationship between purges and imperial control; At the same time, the regional failure of the purges was also shown by the analysis of the following riot happened in Alexandria 361. As for the subsequent studies on imperial control during Julian's reign, the research provided an approach to analyze this theme from three perspectives starting from Purges. Also, these three perspectives can also provide methods for the general studies on the relationship between purges and rule.

\section{REFERENCES}

[1] E. A. Thompson, The Historical Work of Ammianus Marcellinus, in: American Historical Review, 1948(2), pp. 73-74.

[2] Tougher, S, Julian the Apostate. in: Edinburgh University Press, 2007, pp. 44-53. http://www.jstor.org/stable/10.3366/j.ctvxcrk7t

[3] Larry Reedy, Justice at Chalcedon: A Defense of Julian's Political Tribunal, pp. 2-3. https://www.academia.edu/2096749/Justice_at_Ch alcedon_A_Defense_of_Julians_Political_Tribunal, 
[4] L Kaplow, Religious and Intercommunal Violence in Alexandria in the 4th and 5th centuries CE, in: The McGill Journal of Classical Studies 4, 2005, 26(2), pp. 6-9.

[5] Kosaka, S, The Murder of George of Cappadocia and the Violent Pagan Image in Ammianus Marcellinus, in: Scrinium, 2015, 11(1), pp. 64-77. DOI: https://doi.org/10.1163/18177565-00111p09

[6] Marshall Lilly, Companion to the gods, friend to the empire: the experiences and education of the emperor Julian and how it influenced his reign 361-363 AD, 2014, pp. 56-78. Denton, Texas.

[7] Bruno Bleckmann, From Caesar to Augustus: Julian against Constantius, in: Brill's Companions to the Byzantine World, 2020, pp. 1-2.

[8] Blockley, R. C, Constantius Gallus and Julian as Caesars of Constantius II, in: Latomus, 1972, 31(2), pp.433-468. http://www.jstor.org/stable/41503809

[9] Ammianus Marcellinus, Res Gestae, in: https://penelope.uchicago.edu/Thayer/E/Roman/Te xts/Ammian/home.html

[10] Thomas Wright, The Celt, the Roman, and the Saxon, 1902, pp. 144. in: https://searchworks.stanford.edu/view/1664822. 